\title{
The Effects of Future Capital Investment and R\&D EXPENDITURES ON Firms' Liquidity
}

\author{
Christopher F Baum ${ }^{\mathrm{A}, \mathrm{B}, 1}$, Mustafa Caglayan ${ }^{\mathrm{C}}$, Oleksandr Talavera ${ }^{\mathrm{D}}$ \\ ${ }^{a}$ Department of Economics, Boston College, Chestnut Hill, MA 02467 USA \\ ${ }^{b}$ DIW Berlin, Mohrenstraße 58, 10117 Berlin, Germany \\ ${ }^{c}$ Department of Economics, University of Sheffield, Sheffield S10 2TN, UK \\ ${ }^{d}$ Durham Business School, Durham University, Durham DH1 3LB, UK
}

\begin{abstract}
The paper explores factors that lead to accumulation or decumulation of firms' cash reserves. In particular, we empirically examine whether additional future fixed capital and R\&D investment expenditures induce firms to change their liquidity ratio while considering the role of market imperfections. Implementing a dynamic framework on a panel of US, UK and German firms, we find that firms in all three countries make larger adjustments to cash holdings when they plan additional future R\&D rather than fixed capital investment expenditures. This behavior is particularly prevalent among financially constrained firms. (JEL Classification Numbers: G31, G32)
\end{abstract}

Key words: cash holdings, fixed investment, R\&D investment, dynamic panel regression

Email addresses: baum@bc.edu (Christopher F Baum), M.Caglayan@sheffield.ac.uk (Mustafa Caglayan), oleksandr.talavera@durham.ac.uk (Oleksandr Talavera)

${ }^{1}$ Corresponding author. Phone 1-617-552-3673, Fax 1-617-552-2308. 


\section{The Effects of Future Capital Investment and}

\section{R\&D EXPENDITURES ON FIRMS' LIQUIDITY}

\section{Abstract}

The paper explores factors that lead to accumulation or decumulation of firms' cash reserves. In particular, we empirically examine whether additional future fixed capital and R\&D investment expenditures induce firms to change their liquidity ratio while considering the role of market imperfections. Implementing a dynamic framework on a panel of US, UK and German firms, we find that firms in all three countries make larger adjustments to cash holdings when they plan additional future R\&D rather than fixed capital investment expenditures. This behavior is particularly prevalent among financially constrained firms. 


\section{Introduction}

It is important to understand why firms hold substantial amounts of cash, which earns little or no interest, rather than channelling those funds towards capital investment projects or as dividends to shareholders. In an environment with no market imperfections, firms can tap into financial markets costlessly and need not hold cash (Keynes (1936)) as cash has a zero net present investment value (Modigliani \& Miller (1958)). However, in the presence of financial frictions, firms do not undertake all positive net present value projects, but rather choose to save funds for transactions or precautionary motives. In that sense, firms facing market imperfections must choose their level of liquidity at each point in time while taking into account current and future business opportunities.

In this paper we empirically examine the changes in firms' cash holdings, focusing on the effects of future investment expenditures on the accumulation or decumulation of firms' cash reserves. Although we are not the first to investigate how firms' investment expenditures affect their cash holding behavior, our study differs from the rest of the literature on several grounds. An inspection of the literature shows that researchers have recognized the significance of current and future investment plans for liquidity management, yet there seems to be little consensus on how to capture those effects. For instance, some researchers use current investment expenditures or reported investment plans, while others use Tobin's $Q$ to proxy future investment opportunities of the firm. However, all of these strategies have their drawbacks, as we later discuss. In this paper, we examine the effect of one-period-ahead additional investment expenditures on firms' liquidity management behavior. We reason that a rational manager who plans to expand her firm's investment in the next period would take measures to improve the liquid assets of the company so that the project could be realized despite the potential effects of external or internal financial constraints. In such circumstances we should observe that firm's cash holdings will increase.

Our second objective is to examine which type of future investment, fixed capital versus 
R\&D expenditures, would lead to a higher accumulation of cash buffer stocks. We conjecture that an increase in future $R \& D$ expenditures will require firms to increase their cash holdings by more than that of fixed capital expenditures. Our reasoning, similar to that of the earlier literature including Brown \& Petersen (2011), Hall \& Lerner (2009), Bates et al. (2009), and Opler \& Titman (1994), can be explained as follows. In contrast to fixed capital investment, $R \& D$ investment contributes to the stock of intangible capital and cannot be used as collateral. Thus, firms undergoing large $R \& D$ expenditures do not have the financial flexibility of firms that mainly invest in physical capital, as the latter firms may pledge their fixed investment as collateral. As most of a firm's R\&D capital stock is represented by human capital, it would be much more difficult to temporarily reduce $R \& D$ expenditures without losing much of the specialized human capital to other companies. ${ }^{2}$ Therefore, companies that have carried out sizable $R \& D$ activities are more likely to face greater obstacles in accessing external financing in comparison to those firms that have largely invested in pledgeable physical or financial assets. In the presence of financial frictions, this will require firms to hoard more cash should they plan to increase their R\&D expenditures. Another reason linking expansion in R\&D activities to those firms' increase in cash holdings is the fact that R\&D expenditures have a lengthy and highly uncertain payback.

Some studies in the literature have considered the impact of $R \& D$ and fixed investment expenditures along with several potential firm-specific variables which may also affect firms' cash holding behavior. In particular, Bates et al. (2009) examine why cash holdings of US firms increased. They suggest that the precautionary demand for cash can plausibly explain the secular increase in cash holdings, and show that firms whose R\&D expenditures increase hold more cash, while cash is generally negatively correlated with fixed capital

\footnotetext{
${ }^{2}$ As Hall \& Lerner (2009) stress (p. 5), a multi-year purchase of machinery could be rescheduled in the face of financial exigencies, but it would be much more difficult to temporarily reduce R\&D expenditures. They indicate that this is perhaps the most important distinguishing characteristic of R\&D investment, and leads to firms smoothing R\&D spending over time to retain their skilled human capital.
} 
investment. An earlier, influential study by Opler et al. (1999) also implies that firms' cash holdings increase significantly as their capital expenditures-to-assets ratio as well as their R\&D-to-sales ratio increases. In contrast to these studies' findings, Brown \& Petersen (2011) investigate the factors that affect firms' R\&D expenditures and show that in order to smooth their R\&D activities, firms build up their cash reserves when cash flow is available while drawing them down when cash flow is reduced. ${ }^{3}$ In this context, our study is closer to those of Bates et al. (2009) and Opler et al. (1999). However, we investigate firms' cash holding behavior in a dynamic setting as we evaluate the impact of firms' future investment activities on this process, and we deal with issues of endogeneity that are not addressed in those studies. Hence, our work complements the prior literature, as we show that accumulation of cash holdings is related to firms' future investment activities, but is most sensitive to planned R\&D activities. These implications are forthcoming from the analytical findings of Almeida et al. (2011), who present several propositions for firms' choice of liquid vs. illiquid investments, and safe vs. risky assets in the context of future financing constraints.

We should also note that recent research highlights the importance of funds raised from the equity markets to finance R\&D expenditures. Kim \& Weisbach (2008) provide evidence that firms who raise funds through IPOs/SEOs experience an increase in their cash holdings, which is then drawn down to finance various activities including $R \& D$ and fixed investment expenditures. ${ }^{4}$ Observing their findings, although one can suggest that funds raised from public offerings can be stored as cash holdings to finance R\&D expenditures rather than fixed investment, it is well accepted in the literature that financial frictions require managers to hoard cash due to precautionary motives to continue with investment projects when external

\footnotetext{
${ }^{3}$ Brown \& Petersen (2011) do not investigate firms' cash accumulation, but rather consider the role of changes in cash holdings required to smooth their R\&D expenditures.

${ }^{4}$ For instance, they show that in the first year after an IPO, R\&D expenditures increase by 18.5 cents for every dollar of funding raised.
} 
sources of finance may not be available. ${ }^{5}$ For instance, Bates et al. (2009) provide evidence from a panel of US manufacturing firms that although firms' cash holdings have generally increased in recent years, this is not due to new equity issuance. ${ }^{6}$ They show that the observed increase is a reflection of firm characteristics and that the data are consistent with the presence of precautionary savings.

To test the hypothesis that future fixed capital and R\&D investment expenditures have an impact on firms' cash holdings, we use large panels of quoted manufacturing firms obtained from Global COMPUSTAT for the US, UK and Germany over the 1989-2007 period. Our consideration of firms' behavior across these three advanced economies provides broader evidence than the many studies focused on firms in a single country. Cross-country differences in tax regimes, investment incentives, and firms' sources of finance provide an additional source of variation in firms' behavior. ${ }^{7}$

We employ the Dynamic Panel Data System-GMM estimator of Blundell \& Bond (1998) to allow for the possible endogeneity of the explanatory variables. Our approach considers how changes in future investment expenditures may lead to changes in firms' liquidity. In contrast to other studies (e.g., Almeida et al. (2004), Ozkan \& Ozkan (2004) and Baum et al. (2008)) and Bates et al. (2009)) that consider the level of cash holdings, we consider firms' cash accumulation and decumulation. ${ }^{8}$ In estimating our models, we take into account firm-level fixed effects and time effects as well as other firm-specific factors. As the impact of additional investment expenditures may differ across categories of firms due to the presence

\footnotetext{
${ }^{5}$ See, for instance, the first two 'untested direct model implications' in Table 1 of Almeida et al. (2011).

${ }^{6}$ Consideration of new equity issuance in our US sample shows that it represents, for the median firmyear, $0.41 \%$ of total assets and $4.94 \%$ of cash stocks. Thus, we may conclude that adjustments of cash stocks largely reflect use of internal funds.

${ }^{7}$ Baum et al. (2011) find significant differences in the financial constraints faced by firms in different countries depending on the financial structure in which they operate.

${ }^{8}$ Bates et al. (2009) consider models of the level and change in the cash ratio. However, their reliance on OLS in a context with several plausibly endogenous regressors, including capital spending and R\&D expenditures, may cast doubt on their results.
} 
of financial frictions, we consider three sample categorizations based on firms' size, their dividend payout ratio and their dividend status.

Our analysis provides evidence that firms increase their cash holdings by a larger amount when they incur additional future R\&D expenditures than in the case of future fixed capital investment. Scrutinizing the data in more detail, we find that this behavior is particularly prevalent among the so-called 'financially constrained' firms (firms that are small in size, have a low payout ratio, or pay no dividends) that are heavily involved in R\&D activities. Also, similar to the earlier literature, we show that the cash flow sensitivity of cash is higher for constrained firms with respect to their unconstrained counterparts. Robustness checks support our findings.

The rest of the paper is organized as follows. Section 2 briefly reviews the literature. Section 3 presents the model and describes our data. Section 4 provides the empirical results and Section 5 concludes.

\section{Literature Review}

\subsection{Determinants of Cash Holdings}

Keynes (1936) suggests the transaction costs motive and the precautionary motive are the two major reasons why firms hold cash buffers. ${ }^{9}$ To attain a certain level of liquidity, although a firm manager could raise capital by selling assets or issuing new debt or equity, there are significant costs associated with any of these strategies. ${ }^{10}$ Bates et al. (2009) show that over the years, the transactions-based demand for funds declined as both firms and financial intermediaries developed more efficient transactions technologies. However,

\footnotetext{
${ }^{9}$ Keynes (1936) also considers that firms may accumulate cash for speculative purposes. Bates et al. (2009) discuss two other possible motives, based on taxes and agency costs. The tax motive is due to Foley et al. (2007) who suggest that tax considerations might provide incentives for multinational companies to hoard large amounts of cash. The agency motive is argued by Jensen (1986) that entrenched managers prefer to hoard cash, rather than pay dividends, if the firm has poor investment opportunities.

${ }^{10}$ For instance, see Miller \& Orr (1966) who show that firms hold liquid assets as a result of the presence of brokerage costs involved in raising funds.
} 
the precautionary motive, which emphasizes the costs associated with foregone capital investment opportunities due to financial constraints - as well as managers' desire to avoid financial embarrassment in the case of an unexpected shortfall in cash flow-still plays an important role. For instance, many firms have imperfect access to external funds and they cannot borrow sizable sums on short notice, particularly if they experience shortfalls in their cash flow. Furthermore, as firms with weak track records enter the market and experience various firm-specific risks over the business cycle, it would be difficult for firms' managers to successfully raise capital to satisfy their need for liquidity. ${ }^{11}$ In such circumstances, even if a lender is willing to extend external credit, it is likely that the premium will be high. Hence, we would observe that firms follow a financial hierarchy, or 'pecking order', as they first tap cheaper internal sources of funds followed by more expensive alternatives in financing their activities (see Myers (1984) and Myers \& Majluf (1984)). Hence, it should not be surprising to see that those firms which are adversely affected by financial frictions make use of a cash buffer in order to minimize the explicit and implicit costs of liquidity management.

The subsequent empirical literature that builds upon the seminal work of Fazzari et al. (1988) helps us to appreciate why internal funds for the so-called 'financially constrained' firms is an important determinant of capital or R\&D investment behavior. The basic premise in this line of empirical work is to capture the differential impact of cash flow on investment expenditures of firms that are constrained versus those that are not. In other words, the focus of attention is placed on the dependence of constrained firms on internally generated funds. Although there are some challenges with respect to the modeling of the problem, the methodology that one uses to categorize firms, or the control variables used in the model, it is widely accepted that financial market frictions adversely affect capital investment expenditures of the constrained firms in comparison to unconstrained firms. ${ }^{12}$

\footnotetext{
${ }^{11}$ Along these lines see Campbell et al. (2001), Fama \& French (2004) and Irvine \& Pontiff (2009).

${ }^{12}$ See Kaplan \& Zingales (1997), Kaplan \& Zingales (2000), Fazzari et al. (2000), and Erickson \& Whited
} 
Given the developments in the literature on fixed investment behavior of firms and financial frictions, several researchers implement those methodologies to model firms' liquidity behavior. Kim et al. (1998), using a sample of US firms, show that firms facing higher costs of external financing, having more volatile earnings and exhibiting lower returns on assets carry larger stocks of liquid assets. In a similar vein Opler et al. (1999) provide evidence that small firms and firms with strong growth opportunities and riskier cash flows hold larger amounts of cash. ${ }^{13}$ Almeida et al. (2004) show that constrained firms have a positive cash flow sensitivity of cash, while unconstrained firms' cash balance adjustments are not systematically related to cash flows. Sufi (2009), using a panel of US firms, also shows that the cash flow sensitivity of cash is higher for constrained firms, defined as the lack of access to a line of bank credit. Khurana et al. (2006), using data from several countries, find that the sensitivity of cash holdings to cash flows decreases with financial development. In a related study, Faulkender \& Wang (2006) and Pinkowitz \& Williamson (2007) present evidence that the value of cash is higher for constrained firms than for unconstrained firms. ${ }^{14}$

\subsection{Effects of Expected Investment Opportunities on Liquidity}

Although researchers seek to show that firms' cash holdings will be related to their investment opportunities, there is no consensus on how to capture those effects. Researchers (e.g., Opler et al. (1999)) often incorporate firms' current investment expenditures in empirical models to capture the impact of investment opportunities on cash holding behavior. However, empirical models that use current investment expenditures do not necessarily cap-

(2000) for more along these lines.

${ }^{13}$ Pinkowitz \& Williamson (2001) report similar findings for firms in Germany and Japan in addition to those in the US.

${ }^{14}$ There is also active research that relates the value of cash to corporate governance. For instance Dittmar \& Mahrt-Smith (2007) and Harford et al. (2008) present evidence that cash has lower value for firms with weak shareholder rights, pointing out the presence of agency problems. Ozkan \& Ozkan (2004), using a panel of UK firms, show that there is a non-monotonic relationship between managerial ownership and cash holdings. 
ture the effect of future investment. To our knowledge, only Lamont (2000)) has used firms' investment plans, which more closely address the notion that capital expenditures are largely determined for a multiperiod horizon. However, data on investment plans are very limited.

Perhaps the most common approach in the literature is the use of Tobin's $Q$ as a measure of future investment opportunities of firms, although Erickson \& Whited (2000) raise several warnings about this strategy. For instance, Riddick \& Whited (2009), after correcting for measurement error associated with Tobin's $Q$, estimate negative propensities to save out of cash flow. Almeida et al. (2004) replace the standard $Q$ measure in their basic regressions model with the average growth of investment over two periods to capture the impact of current and future investment opportunities on cash holdings. ${ }^{15}$ In a similar vein, Baum et al. (2009) study firms' leverage decisions by employing not current, but realized future values of the level of capital investment. We follow a similar approach in this study.

While acknowledging the importance of expected investment opportunities, few researchers distinguish how different types of investment affect corporate liquidity. As we have discussed above, fixed capital investment leads to the accumulation of pledgeable assets, whereas investment in R\&D may not. We expect that a firm that increases its non-pledgeable investment activities would hold more liquid assets than a similar firm whose assets may readily be pledged as collateral. Notably, Almeida \& Campello (2007) claim that accumulation of pledgeable assets supports more borrowing and hence more capital expenditures. ${ }^{16}$ Bates et al. (2009), implementing a model where they consider firm-specific factors including fixed capital and R\&D expenditures, provide evidence that firms that are R\&D-intensive hold greater cash buffers against future shocks to cash flows. Opler et al. (1999) show that cash holdings increase significantly as firms increase their capital expenditures-to-assets ratio as

\footnotetext{
${ }^{15}$ Time zero investment opportunities are measured as $\left(I_{2}+I_{1}\right) /\left(2 I_{0}\right)$.

${ }^{16}$ Almeida \& Campello (2007) define tangibility as a function of receivables, inventories and capital stock. They also use a proxy to measure how easily lenders can liquidate the firm and another proxy based on product type (durable/nondurable) of each firm.
} 
well as when the R\&D-to-sales ratio increases. More recently, Brown \& Petersen (2011) implement dynamic R\&D investment models that provide evidence on the importance of cash reserves, particularly for young firms. However, in none of these studies do researchers consider firms' demand for liquidity that arises from future investment activities.

There is also a sizable body of research that focuses on the importance of firms' financial constraints and R\&D activities. Bond et al. (2005) suggest that financial constrains affect UK firms' decision to engage in R\&D activity, but not the level of their R\&D expenditures. In a recent paper, $\mathrm{Li}$ (2011) argues that financially constrained R\&D-intensive firms are more likely to terminate R\&D projects. Furthermore, R\&D activities increase the risk of financially constrained firms, which exacerbates their financial frictions. Czarnitzki \& Hottenrott (2011) find that the availability of internal funds has a more sizable impact on R\&D investment, relative to capital investment, for German firms, with the effect being particularly strong for small companies. Using a sample of European firms, Brown et al. (2011) show strong evidence that the availability of finance matters for R\&D even after controlling for the use of external equity financing and smoothing R\&D with cash reserves. Evidence of the effects of financial constrains on R\&D activities is also observed for Dutch (Mohnen et al. (2007)) and Slovenian (Bovha-Padilla et al. (2009)) companies.

In our study, we investigate the impact of two types of firms' future investment activity on the accumulation of cash holdings: R\&D investment versus investment in physical capital. As discussed in the introduction, the former may be considered as intangible capital investment, which has a substantially higher marginal cost of external financing because of its limited pledgeability. Another reason linking expansion in R\&D activities to those firms' increase in cash holdings is the fact that $R \& D$ expenditures have a lengthy and highly uncertain payback. A firm which is engaged in R\&D activity may not realize any benefit in the near future, and may indeed never receive a meaningful return on that investment. This increases the uncertainty surrounding the firm's cash flows and working capital. As Hall 
(2002) points out, uncertain returns from R\&D investment might lead to greater asymmetric information and more serious problems of moral hazard, rendering borrowing a costly option. ${ }^{17}$ Therefore, one would expect that firms planning to expand their R\&D activities would increase their liquid assets in comparison to other firms which only plan to increase their fixed capital.

\section{Empirical Implementation}

\subsection{The Baseline Model}

To quantify the motivation for firms' liquid asset holdings, we use a variant of an empirical specification which is often employed in the literature. The main difference in our approach is the introduction of two types of investment, fixed capital and R\&D, rather than merely focusing on the role of fixed capital investment. Second, we investigate the effect of changes in investment expenditures rather than the level. In doing so we would like to capture the impact of actual changes in investment patterns on the accumulation or decumulation of cash holdings. If the firm changes either sort of future investment by a sizable amount, we expect to find a concomitant change in the firm's cash holdings.

Our baseline model takes the following form:

$$
\begin{aligned}
\Delta \text { Cash }_{i t} & =\alpha_{0}+\alpha_{1} \Delta \text { Cash }_{i, t-1}+\alpha_{2} \text { CashFlow }_{i t}+\alpha_{3} \Delta \text { RD }_{i, t+1} \\
& +\alpha_{4} \Delta \text { FixInv }_{i, t+1}+\alpha_{5} \Delta \text { ShortDebt }_{i t}+\alpha_{6} \Delta N W C_{i t} \\
& +\mu_{i}+\tau_{t}+\epsilon_{i t}
\end{aligned}
$$

where $i$ indexes the firm, $t$ the year, $\Delta$ Cash is a ratio of the change in cash and short term investment to beginning-of-period total assets $\left(\left(\right.\right.$ Cash $_{t}-$ Cash $\left.\left._{t-1}\right) / T A_{t-1}\right)$, and CashFlow is defined as income before extraordinary items plus depreciation, also normalized by total assets. The key coefficients of interest are $\alpha_{3}$ and $\alpha_{4}$, which determine the response

\footnotetext{
${ }^{17}$ Also see Brown \& Petersen (2011), Bates et al. (2009) and Opler \& Titman (1994) along these lines.
} 
of liquid assets' holdings to changes in actual future $\mathrm{R} \& \mathrm{D}, \Delta R D$, and fixed capital investment, $\Delta$ FixInv, respectively. ${ }^{18}$ Additionally, the decision to hold cash crucially depends on changes in net working capital $(\triangle N W C)$ and changes in short term debt $(\Delta$ ShortDebt), which could be considered as cash substitutes. These two firm-specific characteristics are also normalized by beginning-of-period total assets $\left(T A_{t-1}\right)$. The firm and year-specific effects are denoted by $\mu$ and $\tau$, respectively. Finally, $\epsilon$ is an idiosyncratic error term.

We allow for dynamics in the adjustment of cash holdings, as the firm's managers (unbeknownst to the econometrician) may have a multi-year investment plan in place that may imply several years' adjustments to their liquidity ratio. Taking this into account, we believe it is wise to allow the data to indicate whether dynamics in the changes of the liquidity ratio should play a role in the model.

\subsection{The Augmented Model}

While allowing for differences between R\&D and fixed investment's effects on corporate liquidity, Equation (1) does not allow us to explore variations of the cash-future investment sensitivity between financially constrained and unconstrained firms. To investigate this issue as well as the differential impact of cash flow between constrained and unconstrained firms, we specify an extended model in which cash flow and future fixed capital and R\&D investment expenditures are interacted with a vector of firm categories.

The first categorization is based on firm size, given the widespread use of size as a proxy for financial constraints in the literature. For each firm, we compute the annual average of their book value of total assets over the full period for which they are observed. We assign the top and bottom quartiles to large and small firms, respectively, while the two intermediate quartiles constitute medium size firms. The second category is based on the level of the dividend payout ratio. The payout categorization is based on the ratio of common share

\footnotetext{
${ }^{18}$ We define $\Delta R D_{t+1}=\left(R D_{t+1}-R D_{t}\right) / T A_{t}$ and $\Delta F i x \operatorname{Inv}_{t+1}=\left(\operatorname{Inv}_{t+1}-\operatorname{Inv}_{t}\right) / T A_{t}$.
} 
dividend and stock repurchases to total operating income, using the same three quartilebased categories. The third categorization is dichotomous, considering whether the dividend payout ratio is positive or zero. There are disagreements in the empirical literature on the use of the dividend payout ratio (or the presence or absence of dividends) as a proxy for financial constraints. This is all the more important in a cross-country setting with different institutional factors. Thus, for robustness, we use two alternative measures based on the firm's dividend policy.

Our augmented model takes the form

$$
\begin{aligned}
\Delta \text { Cash }_{i t} & =\alpha_{0}+\alpha_{1} \Delta \text { Cash }_{i, t-1}+\left[\text { CashFlow }_{i t} \times T Y P E_{i t}\right] \eta+\left[\Delta R D_{i, t+1} \times T Y P E_{i t}\right] \gamma_{1} \\
& +\left[\Delta \text { FixInv } \text { I }_{i, t+1} \times T Y P E_{i t}\right] \gamma_{2}+\alpha_{5} \Delta \text { ShortDebt }_{i t}+\alpha_{6} \Delta N W C_{i t} \\
& +\mu_{i}+\tau_{t}+\epsilon_{i t}
\end{aligned}
$$

where $T Y P E_{i t}$ is a vector of dummies capturing one of the categorizations of firms as more or less likely to face financial constraints.

To aid in comparing results across categories, we estimate a single model where we interact the category indicators with cash flow and changes of future investment. ${ }^{19}$ This approach allows us to properly conduct a test of coefficients' stability over these categories of firms. This strategy also allows firms to transition among categories, year by year, rather than categorizing them once and for all.

To estimate equations (1) and (2) we must take into account the endogeneity of financial and investment decisions. In particular, including the lagged dependent variable as an explanatory variable renders a fixed effects estimator biased and inconsistent (see Nickell (1981)). To overcome this difficulty previous researchers relied heavily on using various GMM-family estimators (e.g. IV or 2SLS). However, quite often the choice of instruments

\footnotetext{
${ }^{19}$ As a robustness check, Section 4.3.4 presents a set of regressions which we carry out for separate categories. Regression results obtained from this investigation provide further support for our main hypothesis.
} 
in those settings requires very careful justification. To address this critique, we employ the Dynamic Panel Data (DPD) estimator that proposes an appropriate set of instruments by construction. All our models are estimated with the two-step GMM-System estimator, which combines equations in differences of the variables with equations in levels of the variables. Individual firm fixed effects are removed by using a first difference transformation.

The reliability of our econometric methodology depends crucially on the validity of the instruments, which can be evaluated with the Sargan-Hansen $J$ test of overidentifying restrictions, asymptotically distributed as $\chi^{2}$ in the number of restrictions. A rejection of the null hypothesis that instruments are orthogonal to the error process would indicate that the estimates are not consistent. We also present test statistics for second-order serial correlation in the error process. In a dynamic panel data context, we expect first order serial correlation, but should not be able to detect second-order serial correlation if the instruments are appropriately uncorrelated with the errors. Our instrument sets have been chosen to ensure that the orthogonality conditions are satisfied, and that we have avoided the issue of "too many instruments' discussed in Roodman (2009b). In particular, it is well known that p-values of 1.00 for Hansen $J$ tests indicate that the test of overidentifying restrictions lacks sufficient power to reject its null in the presence of too many instruments. The GMM-System approach creates a plethora of instruments, as separate instruments are constructed for the difference and level equations. We report the number of instruments used in each specification, which should be well below the number of observations entering the regression. In all cases, the number of instruments is no greater than $18 \%$ of the number of firm-years, and on average is between $8-11 \%$ of the number of firm-years.

As Roodman (2009a) suggests, it is usually necessary to limit the lags of endogenous variables used as 'GMM-style' instruments. We have done so, with lag lengths between 2 and 4 periods applied to the endogenous variables. To ensure validity, we have not included the first or second lags of changes in actual future $\mathrm{R} \& \mathrm{D}, \Delta R D$, and fixed investment, $\Delta$ Fix Inv. 
For those variables, lag lengths between 3 and 5 periods have been chosen. The instrument lag structure for each model has been chosen to ensure that the p-value of the Hansen $J$ statistic is below unity wherever possible. In each of the models presented below, the Hansen $J$ statistic for overidentifying restrictions and the Arellano-Bond $\operatorname{AR}(2)$ tests show that our instruments are appropriate and no second order serial correlation is detected, respectively.

\subsection{Data}

In our empirical investigation we use manufacturing firm-level data extracted from S\&P's Global COMPUSTAT database which reports accounting information on large corporations. Although this dataset covers a number of countries, we constrain our investigation to three advanced economies: the US, UK and Germany. These three advanced economies each have significant manufacturing sectors - particularly Germany, the world's leading exporter — but emphasize different industrial sectors in terms of both capital investment and R\&D expenditures. ${ }^{20}$ These countries allow us to have a reasonably large sample which is essential to satisfy the asymptotic properties of the GMM-System estimator.

In total, our sample consists of an unbalanced panel of about 32,000 manufacturing firmyear observations over the period from 1989-2007. ${ }^{21}$ Prior to estimating our models we apply a number of sample selection criteria which roughly follow Almeida et al. (2004). First, we retain companies which have not undergone substantial changes in their composition during the sample period (e.g., participation in a merger, acquisition or substantial divestment). As these phenomena are not observable in the data, we calculate the growth rate of each firm's total assets and sales, and trim the annual distribution of these growth rates exceeding

\footnotetext{
${ }^{20}$ Data availability limits the possibility to consider other leading economies: for instance, although the dataset provides information on a large sample of Japanese firms, data on fixed capital investment are not available.

${ }^{21} \mathrm{~A}$ firm is considered in the manufacturing sector if its two-digit US Standard Industrial Classification (SIC) code is in the 20-39 range. The database provides this code for non-US firms as well.
} 
$100 \% .^{22}$ Second, we remove all firms that have fewer than three observations over the time span. Third, the top and bottom 1\% observations of all firm-specific variables are winsorized. Missing values of R\&D expenditures are replaced with zeros. Finally, we drop all those companies that have cash flow-to-assets ratio lower than $-0.5(-50 \%)$ for at least three years to remove those companies in financial distress. ${ }^{23}$ The screened US sample is the largest and consists of 17,813 observations pertaining to 2,006 companies. The German and UK screened samples consist of 2,306 (352 firms) and 3,202 (505 firms) firm-years' data, respectively. All data items are transferred into US dollars and CPI adjusted.

Descriptive statistics for the firm-year observations entering the analysis are presented in Table 1. As anticipated, there are considerable variations in liquidity ratios across countries. The highest average liquidity ratio $(14.4 \%)$ is maintained by US companies, while the lowest $(8.6 \%)$ is found for companies headquartered in Germany. Importantly, Table 1 shows that those US companies that are involved in $R \& D$ invest almost as much in $R \& D$ as in fixed capital, while UK firms have a smaller R\&D to asset ratio and German firms have the smallest. We should also note that German firms maintain the highest fixed investment rates and the highest short-term debt among the three countries.

\section{Empirical Results}

\subsection{Contrast with the Model of Almeida et al. (2004)}

Our model can be considered an extension of that developed by Almeida et al. (2004) to estimate the change in cash holdings $(\Delta C)$ caused by changes in cash flow and Tobin's $\mathrm{Q}$, controlling for firm size. ${ }^{24}$ In their model, investment opportunities are proxied by Tobin's Q. Our data do not include firms' market value, so we cannot directly estimate their model. We

\footnotetext{
${ }^{22}$ We experimented with a more restrictive definition and received quantitatively similar results.

${ }^{23}$ In total, 104 firms have been removed.

${ }^{24}$ We are grateful to an anonymous reviewer for suggesting this discussion be added to the manuscript.
} 
proxy Tobin's Q with the ratio of realized future investment to current investment, defined in their footnote 20 as $\left(I_{1}+I_{2}\right) /\left(2 \times I_{0}\right)$.

To illustrate how our modeling strategy differs from that of Almeida et al. (2004), we present fixed effects results using US, German and UK firms' data in Table 2, which shows results from estimating their Equation (8), page 1787, augmented with actual future R\&D, $\Delta N W C, \Delta$ ShortDebt, $\Delta R D$, and $\Delta F i x I n v$. For comparability, we ignore issues of potential endogeneity and employ OLS with firm-level fixed effects. Column (1) presents results for US companies. The common coefficients are quantitatively similar to Almeida et al. (2004)'s results. Our US estimates also contain positive and significant coefficients for the coefficients on $\Delta R D$ and $\Delta F i x I n v$. However for the UK and German firms (Columns 2 and 3, respectively), the Almeida-style results contain insignificant coefficients on the planned R\&D variable. We believe this reflects the serious econometric issues raised by the application of an OLS fixed effects approach. The proxy for Tobin's Q introduces obvious measurement error problems, and ignoring the possible endogeneity in other regressors casts doubt on the validity of these estimates. For that reason, we do not carry out additional exercises with this model, which in any case is not in line with the focus of our study. We believe that adjustment of the firm's cash buffer stock should be treated as an explicitly dynamic process. The sizable and significant coefficients on the lagged dependent variables in our chosen specifications support that interpretation, rendering a fixed effects model biased (per Nickell (1981)) and inconsistent.

\subsection{The Baseline Model}

We continue our investigation by implementing a dynamic model (Equation 1) for each country to explore the effects of cash flow, lagged change in cash holding, change in future R\&D and fixed capital investment expenditures, and changes in non-cash net working capital and short-term debt ratios on firms' cash holding behavior. Our premise is that cash flow and future R\&D and fixed investment expenditures should have positive and significant 
coefficients, with the impact of increases in R\&D expenditures greater than that of increases in fixed capital investment expenditures, as explained earlier. The coefficients of changes in the non-cash net working capital and short-term debt ratios are expected to be negative. The impact of R\&D expenditures are likely to be most significant for the US firms, as the data show that US firms are more heavily engaged in R\&D activities.

It is useful to note that there are many firms in each country's sample that do not report positive $R \& D$ spending in any year. If we were attempting to model the firm's decision to carry out R\&D, and if so how much to spend, we would have to take that stylized fact into account. In our context, as R\&D expenditures only appear on the right side of our estimated equations, the distribution of that variable is not a concern. In fact, we do not consider the level of expenditures, but only its change, $\Delta \mathrm{RD}_{i, t+1}$. In that context, a firm that never carries out R\&D and a firm that always spends the same amount on R\&D are observationally equivalent. To the extent that zero R\&D expenditures are commonly observed-e.g., the median values of R\&D spending in Germany and the UK are both zero- our findings of the importance of future changes in spending as an important determinant of firms' liquidity adjustments are all the more meaningful.

Table 3 presents the results for the dynamic model given in Equation (1). The change in future fixed investment expenditures is positive for all countries but it is only significant for the US at the five percent level. That is, an increase in fixed investment behavior does not necessarily lead to a significant change in cash holdings. This evidence could be explained by the pledgeability of investments in physical capital. Bester (1985) argues that collateral can be used as a signaling mechanism to distinguish between high-risk and low-risk borrowers. In contrast, $R \& D$ capital has limited collateral value and it is a riskier type of investment. We expect that those firms that are planning to increase their R\&D investment expenditures are likely to accumulate liquid assets to finance this type of investment. We find support for this conjecture. Table 3 provides evidence that the effect of the change 
in future $R \& D$ expenditures leads to a positive and significant increase in liquidity (at the one percent level for the US and Germany and at the five percent level for the UK). This observation implies that firms increase their current cash holdings in anticipation of next period's R\&D expenditures. Furthermore, given the results we can say that firms accumulate more cash for future R\&D expenditures than for future fixed investment expenditures, as captured by the relative magnitudes of their coefficients. The tests of equality of $\gamma_{\Delta R D}$ and $\gamma_{\Delta \text { FixInv }}$ coefficients yields $p$-values of less than 0.10 , unambiguously rejecting the null of equal coefficients.

In Table 3 the coefficient on the lagged dependent variable for all countries is significant and negative, implying that dynamics of the cash adjustment process are important. Interestingly, our coefficient estimates are very similar to those reported on a firm level by Opler et al. (1999) from their Eqn. 1, a pure autoregressive model of the change in the cash/assets ratio. They find a median coefficient of -0.242 at the firm level. ${ }^{25}$ The table also shows that an increase in cash flow leads to an accumulation of cash for all countries, as its coefficient is positive and significant for all three countries at the $1 \%$ level. As earlier research has shown, changes in the non-cash net working capital ratio possess negative and significant coefficients for all countries. Finally, we find that the change in the short-term debt ratio has a negative and significant effect on cash accumulation for UK firms, but an insignificant effect in the US and Germany.

\subsection{The Augmented Model}

The results given in Tables 4, 5 and 6 present our findings for Equation (2) where we model firms' adjustment of their cash balances for different size, dividend and payout categories, respectively. Each table depicts six models (two per country) where columns 1, 3 and 5 only

\footnotetext{
${ }^{25}$ Opler et al. (1999), in their full models, include last period's deviation from a target cash ratio as an explanatory factor, using several definitions of the target cash ratio. As we are not testing the 'static tradeoff' model, we do not include this complication in our dynamic specification.
} 
allow the cash flow coefficients to differ across categories. In columns 2,4 and 6 , interactions with R\&D and fixed investment are also included, per Equation (2).

\subsubsection{Firms' Liquidity and the Role of Firm Size}

Table 4 presents our results for Equation (2) for different firm size categories. Comparing results from this table with that of Table 3, we see that the lagged dependent variable and the changes in non-cash net working capital ratios have similar significance and effects on firms' adjustments of their liquidity. Our results show that small firms contribute to their liquidity more than their larger counterparts do as their cash flow increases. In line with earlier research, cash flow has a small and insignificant effect on large firms' liquidity behavior across all three countries. Although the differences between these effects' magnitudes across size categories are generally not statistically significant, the point estimates clearly suggest the greater importance of cash flow for smaller firms.

Having examined the impact of cash flow across different size categories, we next consider the effects of R\&D and fixed capital expenditure on the liquidity behavior of firms as firm size is allowed to change for the same set of models. Columns 1,3 , and 5 of the table show that future capital investment expenditures affect US firms' liquidity at the one percent level while the effect is insignificant for the other countries. In contrast, future change in R\&D affects liquidity in all three countries positively and significantly: at the five percent level for US firms and the ten percent level for UK and German firms.

We next allow the impact of the change in $R \& D$ and fixed investment to differ across different categories along with the effect of cash flow. Inspecting the results given in columns 2, 4 and 6, we see that only US small firms' liquidity responds to an increase in future capital investment expenditures. When we consider the effects of future R\&D expenditures, we find that small firms' future R\&D expenditures have a significant and large impact on firms' liquidity, yet we find no such effect for medium or large firms. This means that medium and large firms do not significantly increase their liquidity in response to an increase in 
future R\&D expenditures. Financially constrained firms tend to save more in comparison to unconstrained firms, with future R\&D expenditures emerging as an important factor that induces firms to adjust their cash holdings.

\subsubsection{Firms' Liquidity and the Dividend Payout Ratio}

Our second categorization is based on firms' payout ratios. This categorization allows us to generate three groups of firms, with low, medium and high dividend payout ratios. We follow this approach due to the observation that most German and UK firms pay dividends while some of these may be in fact financially constrained. Hence, inspection of German and UK firms using this categorization may help us to understand the effects of the changes in future R\&D and fixed investment activities. The disadvantage of this route is that we will allocate some of the non-dividend paying US firms, which are generally considered by researchers as financially constrained, to another category. Hence, we would expect that when evaluating results for US firms that low and medium payout firms in the US would have similar characteristics.

Table 5 presents our regression results when we investigate firms' liquidity behavior categorizing the firms with respect to their dividend payout ratio. In line with our earlier results, the coefficient of the lagged dependent variable is negative and significant. Also, the significance and sign of changes in the non-cash net working capital and short-term debt ratios are unchanged. We also observe that while cash flow for low and medium payout firms has a positive and significant effect on liquidity the impact of cash flow on those firms that are in the large payout category, although positive, is insignificant.

When we inspect the impact of a change in future fixed investment on liquidity we find that the effect is positive for all countries for those countries in the low payout group yet significant only for the US and the UK. In all cases, changes in future capital investment does not lead to an increase in firms' liquidity for medium and high payout firms. When we examine the impact of a change in future $R \& D$ expenditure, we find that low payout firms 
increase liquidity in all countries. In the US, firms that are in the medium payout category also increase their liquidity. As discussed earlier, an increase in future R\&D investment induces financially constrained firms to increase their liquidity. While similar behavior is observed for those firms that increase their fixed capital investment, the evidence is not as broad as in the case of $R \& D$ investment, and the size of the impact on liquidity is always smaller than that of a change in future R\&D investment.

\subsubsection{Firms' Liquidity and Dividend Status}

Table 6 presents our regression results when we investigate firms' liquidity behavior comparing dividend-paying with non-dividend-paying firms. In all models, the coefficient of the lagged dependent variable is negative and significant, indicating that dynamics play an important role in this relationship. The significance and sign of changes in the non-cash net working capital and short-term debt ratios are unchanged: non-cash net working capital is negative and significant for US and UK firms but insignificant for German firms, while the short-term debt ratio is negative for all cases but significant only for UK firms (see column 5). When we inspect the effect of cash flow for dividend-paying versus non-dividend-paying firms, we see that non-dividend-paying US firms increase their liquidity significantly in comparison to their dividend-paying counterparts. For the case of German and UK firms we find no difference across dividend paying and non-dividend paying firms, as an increase in their cash flow leads to an increase in their liquidity.

Next we concentrate on the effects of fixed capital investment and R\&D expenditures. In contrast to the results presented in Table 4, when we categorize the firms between dividendpaying and non-dividend paying firms, we see no differential effect of future fixed investment expenditures on either type of firms' liquidity behavior. However, when we inspect the impact of an increase in future $R \& D$ expenditures, we see that non-dividend-paying firms augment their liquidity, while dividend-paying firms do not significantly change their liquidity behavior. This pattern holds for firms in all three economies, supporting the claim that an 
increase in future R\&D expenditures leads to an increase in financially constrained firms' liquidity.

\subsubsection{Robustness checks and a general discussion}

The augmented model presented in Tables 4, 5 and 6 constrains some of the coefficients (e.g., that of the lagged dependent variable, $\Delta$ Cash $_{t-1}$ ) to a single value for different size classes and dividend categories. This makes it possible to perform formal tests of coefficient variation across categories in the context of a single equation. Nevertheless, one may suspect that equations fit separately to each category might exhibit different dynamic behavior. ${ }^{26}$ To evaluate the robustness of our findings, we present results obtained from estimating separate equations for the whole sample and four subsamples (small and large firms, and each dividend category) of US firms. In doing so, we also include the lagged ratio of new equity issuance to total assets in the model to investigate whether funds raised from equity issuance will impact firms' cash accumulation behavior along the lines suggested by Kim \& Weisbach (2008). ${ }^{27,28}$ The inclusion of this variable allows us to consider whether the coefficients associated with future fixed investment and R\&D expenditures will be qualitatively affected or not. ${ }^{29}$

These results, for the baseline model, are presented in Table $7 .{ }^{30}$ Column 1 reports results for the entire set of US firms, while estimates in columns (2)-(5) are based on subsamples of small, large, no-dividend-paying and dividend-paying firms, respectively. In general, the subsample results are qualitatively similar to those presented for the entire set of US firms

\footnotetext{
${ }^{26}$ We are grateful to an anonymous reviewer for suggesting that this discussion be added to the manuscript.

${ }^{27}$ The median values of this ratio are 0.004 for the current firm-year, 0.006 averaged over the prior three firm-years, and 0.008 averaged over the past five firm-years.

${ }^{28}$ Results do not differ when the current ratio of new equity issuance to total assets is used instead of its lag.

${ }^{29}$ We cannot carry out this exercise for the UK and German subsamples as information on new equity issuance is only available for US companies.

${ }^{30}$ Estimation of a dynamic panel data model for subsamples is not workable if firms frequently switch between subsamples. In order to define stable subsamples, we define a dividend-paying firm as a firm that paid dividends in $50 \%$ or more of observed firm-years, and vice versa.
} 
in column (1). We find that the effect of changes in future capital investment is precisely estimated in the dividend-paying subsample, but not in the other three subsamples. In these three subsamples, the effects of changes in future R\&D expenditures on cash holdings are precisely estimated. Financially constrained (small or no-dividend-paying) firms have a greater sensitivity to cash flow and are more likely to adjust their cash stock in anticipation of changes in future R\&D expenditures. For small and non-dividend-paying firms, the effects of planned R\&D and fixed investment are statistically distinguishable at the five per cent level, and at the six per cent level for all firms. Although, per expectation, new equity issuance has a uniformly positive effect on firms' cash accumulation, the impact of the remaining variables on cash accumulation is not meaningfully altered by its inclusion. The positive coefficient on new equity issuance suggests that firms use the funds they raise to increase their cash holdings, quite possibly to finance investment expenditures in subsequent years, as Kim \& Weisbach (2008) suggest. ${ }^{31}$ However, this effect appears to be weak and we do not explore this idea further, as it is beyond the objective of this paper. ${ }^{32}$

A potential issue to be considered in future research is the observational similarity between the R\&D interaction coefficients of small and large US firms, or dividend-paying or non-paying US firms. For instance in Table 5, although the coefficient of the low payoutR\&D interaction is insignificant and that of the high payout-R\&D interaction is significant, these coefficients cannot be statistically distinguished from each other. This finding for US firms somewhat weakens the suggestion that financial market frictions affect smaller firms more severely than larger firms. However, in the UK and German subsamples, the same set of coefficients are statistically distinguishable, implying the presence of financial market frictions. The result for US firms could be driven by a number of reasons including the fact

\footnotetext{
${ }^{31}$ We thank an anonymous reviewer for suggesting this interpretation.

${ }^{32}$ It may also be the case that the timing of new equity issuance is driven by market timing issues and underwriters' recommendations. See Kim \& Weisbach (2008) along these lines.
} 
that the US firms included in the Global COMPUSTAT database are not really small firms. Another possibility is that US firms might have greater access to external finance than their foreign counterparts, regardless of their size, given the greater development of the private equity and venture capital channels in the US. For future research, it would be useful to explore this idea using a wider variety set of firms which differ in size and access to financial markets. For instance, it would be useful to look into public versus non-public firm behavior.

\section{Conclusions}

In this paper we empirically examine the factors that affect the accumulation or decumulation of cash reserves of firms using data from three advanced economies: the US, UK and Germany. Our investigation specifically considers the impact of future fixed capital and R\&D expenditures on firms' liquidity behavior. Although one can expect that an increase in either type of investment will lead to an improvement in firms' cash holdings, we conjecture that the effect of R\&D expenditures on firms' cash holdings should be stronger based on the observation that R\&D investment leads to accumulation of intangible assets and yields highly uncertain returns. As a result, asymmetric information problems weigh more heavily in the case of $R \& D$ investment in comparison to investment in fixed capital, rendering $R \& D$ activity more dependent on internal financial resources.

To carry out our investigation, we use panels of quoted manufacturing firms obtained from Global COMPUSTAT for the US, UK and Germany over 1989-2007. The empirical models implement a dynamic framework to allow the adjustment of cash balances to reflect the many unobserved factors that may be associated with firms' multi-year investment plans for both fixed capital and R\&D expenditures. We also consider the impact of market imperfections resulting in financial constraints by categorizing firms based on size, dividend payout ratio and dividend status. Our analysis reveals that firms in each country augment their cash holdings more vigorously in response to additional future $R \& D$ expenditures than they do for increases in future fixed capital investment. Scrutinizing the data in more detail, we 
find that this behavior is particularly prominent among firms more likely to be financially constrained: small, low-payout firms or those who do not pay dividends. In line with the earlier literature, we also show that point estimates of the cash flow sensitivity of cash is higher for constrained firms with respect to their larger counterparts in all three countries. The results for US firms are robust to the inclusion of new equity issuance as a source of cash.

From the policy perspective, one cannot underestimate the importance of technologyproducing mechanisms for knowledge-based economies. Our study reveals that companies that plan to increase their R\&D activities would increase their cash buffers, implying their need for internally generated funds. This observation holds for all countries in our dataset. In that sense, our findings are unique in light of previous studies, which have not shown such diverse and significant effects. In particular we show that future R\&D investment has an economically significant effect on firms' liquidity behavior, and that this effect is much larger than that related to future fixed investment. Robustness checks support these findings and our hypotheses relating to the severity of financial frictions.

\section{Acknowledgements}

We acknowledge the constructive suggestions of two anonymous reviewers. We are also grateful for the comments of participants at the 28th GdRE International Annual Symposium on Money, Banking and Finance, 2011; the Sixteenth Annual Conference on Panel Data, 2010; and seminar participants at Queen's University Belfast, the University of York, the National University of Singapore and OFCE/SKEMA Business School, Sophia Antipolis. 


\section{References}

Almeida, H. \& Campello, M. (2007), 'Financial constraints, asset tangibility, and corporate investment', Review of Financial Studies 20(5), 1429-1460.

Almeida, H., Campello, M. \& Weisbach, M. (2004), 'The cash flow sensitivity of cash', Journal of Finance 59(4), 1777-1804.

Almeida, H., Campello, M. \& Weisbach, M. S. (2011), 'Corporate financial and investment policies when future financing is not frictionless', Journal of Corporate Finance 17(3), 675693.

Bates, T. W., Kahle, K. M. \& Stulz, R. M. (2009), 'Why do U.S. firms hold so much more cash than they used to?', Journal of Finance 64(5), 1985-2021.

Baum, C. F., Caglayan, M., Stephan, A. \& Talavera, O. (2008), 'Uncertainty determinants of corporate liquidity', Economic Modelling 25(5), 833-849.

Baum, C. F., Schäfer, D. \& Talavera, O. (2011), 'The impact of the financial system's structure on firms' financial constraints', Journal of International Money and Finance 30, 678-691.

Baum, C. F., Stephan, A. \& Talavera, O. (2009), 'The effects of uncertainty on the leverage of nonfinancial firms', Economic Inquiry 47(2), 216-225.

Bester, H. (1985), 'Screening vs. rationing in credit markets with imperfect information', American Economic Review 75(4), 850-55.

Blundell, R. \& Bond, S. (1998), 'Initial conditions and moment restrictions in dynamic panel data models', Journal of Econometrics 87, 115-143.

Bond, S., Harhoff, D. \& Reenen, J. V. (2005), 'Investment, R\&D and financial constraints in Britain and Germany', Annales d'Economie et de Statistique 79-80, 433-460.

Bovha-Padilla, S., Damijan, J. P. \& Konings, J. (2009), Financial constraints and the cyclicality of R\&D investment:evidence from Slovenia, LICOS Discussion Papers 23909, LICOS - Centre for Institutions and Economic Performance, K.U.Leuven.

Brown, J. R., Martinsson, G. \& Petersen, B. C. (2011), Do financing constraints matter for R\&D?, Discussion Paper 1684731, SSRN.

Brown, J. R. \& Petersen, B. C. (2011), 'Cash holdings and R\&D smoothing', Journal of Corporate Finance 17(3), 694-709. 
Campbell, J. Y., Lettau, M., Malkiel, B. G. \& Xu, Y. (2001), 'Have individual stocks become more volatile? An empirical exploration of idiosyncratic risk', Journal of Finance 56(1), 143.

Czarnitzki, D. \& Hottenrott, H. (2011), 'R\&D investment and financing constraints of small and medium-sized firms', Small Business Economics 36, 65-83.

Dittmar, A. \& Mahrt-Smith, J. (2007), 'Corporate governance and the value of cash holdings', Journal of Financial Economics 83(3), 599-634.

Erickson, T. \& Whited, T. M. (2000), 'Measurement error and the relationship between investment and q', Journal of Political Economy 108(5), 1027-1057.

Fama, E. F. \& French, K. R. (2004), 'New lists: Fundamentals and survival rates', Journal of Financial Economics 73(2), 229-269.

Faulkender, M. \& Wang, R. (2006), 'Corporate financial policy and the value of cash', Journal of Finance 61(4), 1957-1990.

Fazzari, S., Hubbard, R. G. \& Petersen, B. C. (1988), 'Financing constraints and corporate investment', Brookings Papers on Economic Activity 19(2), 141-195.

Fazzari, S. M., Hubbard, R. G. \& Petersen, B. C. (2000), 'Investment-cash flow sensitivities are useful: A comment on Kaplan and Zingales', Quarterly Journal of Economics 115(2), 695-705.

Foley, C. F., Hartzell, J. C., Titman, S. \& Twite, G. (2007), 'Why do firms hold so much cash? A tax-based explanation', Journal of Financial Economics 86(3), 579-607.

Hall, B. H. (2002), 'The financing of research and development', Oxford Review of Economic Policy 18(1), 35-51.

Hall, B. H. \& Lerner, J. (2009), The financing of R\&D and innovation, NBER Working Papers 15325, National Bureau of Economic Research, Inc.

Harford, J., Mansi, S. A. \& Maxwell, W. F. (2008), 'Corporate governance and firm cash holdings', Journal of Financial Economics 87(3), 535-555.

Irvine, P. J. \& Pontiff, J. (2009), 'Idiosyncratic return volatility, cash flows, and product market competition', Review of Financial Studies 22(3), 1149-1177.

Jensen, M. C. (1986), 'Agency costs of free cash flow, corporate finance, and takeovers', American Economic Review 76(2), 323-29.

Kaplan, S. N. \& Zingales, L. (1997), 'Do investment-cash flow sensitivities provide useful measures of financing constraints', Quarterly Journal of Economics 107(1), 196-215. 
Kaplan, S. N. \& Zingales, L. (2000), 'Investment-cash flow sensitivities are not valid measures of financing constraints', Quarterly Journal of Economics 115(2), 707-712.

Keynes, J. M. (1936), The general theory of employment, interest and money, London, Harcourt Brace.

Khurana, I. K., Martin, X. \& Pereira, R. (2006), 'Financial development and the cash flow sensitivity of cash', Journal of Financial and Quantitative Analysis 41(4), 787-808.

Kim, C.-S., Mauer, D. C. \& Sherman, A. E. (1998), 'The determinants of corporate liquidity: Theory and evidence', Journal of Financial and Quantitative Analysis 33, 335-359.

Kim, W. \& Weisbach, M. S. (2008), 'Motivations for public equity offers: An international perspective', Journal of Financial Economics 87(2), 281-307.

Lamont, O. A. (2000), 'Investment plans and stock returns', Journal of Finance 55(6), 27192745.

Li, D. (2011), 'Financial constraints, R\&D investment, and stock returns', Review of Financial Studies 24(9), 2974-3007.

Miller, M. H. \& Orr, D. (1966), 'A model of the demand for money by firms', Quarterly Journal of Economics 80(3), 413-435.

Modigliani, F. \& Miller, M. (1958), 'The cost of capital, corporate finance, and the theory of investment', American Economic Review 48(3), 261-297.

Mohnen, P., Tiwari, A., Palm, F. \& Schim van der Loeff, S. (2007), Financial constraint and R\&D investment: Evidence from CIS, UNU-MERIT Working Paper Series 011, UNUMERIT.

Myers, S. C. (1984), 'The capital structure puzzle', Journal of Finance 39(3), 575-92.

Myers, S. C. \& Majluf, N. S. (1984), 'Corporate financing and investment decisions when firms have information that investors do not have', Journal of Financial Economics 13, $187-221$.

Nickell, S. (1981), 'Biases in dynamic models with fixed effects', Econometrica 49, 1417-1426.

Opler, T. C. \& Titman, S. (1994), 'Financial distress and corporate performance', Journal of Finance 49(3), 1015-40.

Opler, T., Pinkowitz, L., Stulz, R. \& Williamson, R. (1999), 'The determinants and implications of corporate cash holdings', Journal of Financial Economics 52, 3-46. 
Ozkan, A. \& Ozkan, N. (2004), 'Corporate cash holdings: An empirical investigation of UK companies', Journal of Banking and Finance 28, 2103-2134.

Pinkowitz, L. \& Williamson, R. (2001), 'Bank power and cash holdings: Evidence from Japan', Review of Financial Studies 14(4), 1059-82.

Pinkowitz, L. \& Williamson, R. (2007), 'What is the market value of a dollar of corporate cash?', Journal of Applied Corporate Finance 19(3), 74-81.

Riddick, L. A. \& Whited, T. M. (2009), 'The corporate propensity to save', Journal of Finance 64(4), 1729-1766.

Roodman, D. (2009a), 'How to do xtabond2: An introduction to difference and system GMM in Stata', Stata Journal 9(1), 86-136.

Roodman, D. (2009b), 'A note on the theme of too many instruments', Oxford Bulletin of Economics and Statistics 71(1), 135-158.

Sufi, A. (2009), 'Bank lines of credit in corporate finance: An empirical analysis', Review of Financial Studies 22(3), 1057-1088. 
Table 1: Descriptive statistics: All firms, 1989-2007

\begin{tabular}{lcccc}
\hline \hline & & & & \\
Panel A: US & & & & \\
\hline Variable & $\mu$ & $\sigma$ & Median & $\mathrm{N}$ \\
\hline Cash & 0.144 & 0.176 & 0.070 & 17,813 \\
Cash Flow & 0.067 & 0.127 & 0.089 & 17,813 \\
R\&D & 0.048 & 0.077 & 0.019 & 17,813 \\
Fixed Investment & 0.052 & 0.041 & 0.042 & 17,813 \\
Short Term Debt & 0.024 & 0.054 & 0.000 & 17,813 \\
\hline & & & & \\
Panel B: Germany & & & & \\
\hline Variable & $\mu$ & $\sigma$ & Median & $\mathrm{N}$ \\
\hline Cash & 0.086 & 0.101 & 0.049 & 2,306 \\
Cash Flow & 0.080 & 0.096 & 0.087 & 2,306 \\
R\&D & 0.013 & 0.035 & 0.000 & 2,306 \\
Fixed Investment & 0.068 & 0.049 & 0.058 & 2,306 \\
Short Term Debt & 0.109 & 0.111 & 0.068 & 2,306 \\
\hline & & & & \\
Panel C: UK & & & & \\
\hline Variable & $\mu$ & $\sigma$ & Median & $\mathrm{N}$ \\
\hline Cash & 0.113 & 0.134 & 0.071 & 3,202 \\
Cash Flow & 0.077 & 0.119 & 0.097 & 3,202 \\
R\&D & 0.020 & 0.054 & 0.000 & 3,202 \\
Fixed Investment & 0.060 & 0.044 & 0.051 & 3,202 \\
Short Term Debt & 0.073 & 0.083 & 0.045 & 3,202 \\
\hline \hline
\end{tabular}

Note: All figures are calculated as ratios to the firm's total assets. $\mu$ and $\sigma$ represent mean and standard deviation respectively. $N$ is the number of firm-years. 
Table 2: Fixed effects estimates of $\Delta$ Cash

\begin{tabular}{|c|c|c|c|}
\hline & $\begin{array}{l}\text { US } \\
\quad(1)\end{array}$ & $\begin{array}{r}\text { Germany } \\
(2)\end{array}$ & $\begin{array}{l}\text { UK } \\
(3)\end{array}$ \\
\hline Cash Flow $_{t}$ & $\begin{array}{r}0.286^{* * * *} \\
(0.016)\end{array}$ & $\begin{array}{r}0.126^{* *} \\
(0.054)\end{array}$ & $\begin{array}{r}0.212^{* * *} \\
(0.033)\end{array}$ \\
\hline $\mathrm{Size}_{t}$ & $\begin{array}{r}0.015^{* * *} \\
(0.002)\end{array}$ & $\begin{array}{r}0.024^{* * *} \\
(0.006)\end{array}$ & $\begin{array}{r}0.020 * * * \\
(0.006)\end{array}$ \\
\hline $\mathrm{Q} \operatorname{Proxy}_{t}$ & $\begin{array}{r}0.005^{* * *} \\
(0.001)\end{array}$ & $\begin{array}{r}0.001 \\
(0.001)\end{array}$ & $\begin{array}{r}0.000 \\
(0.001)\end{array}$ \\
\hline$\Delta \mathrm{NWC}_{t}$ & $\begin{array}{r}-0.249^{* * *} \\
(0.016)\end{array}$ & $\begin{array}{r}-0.085^{* *} \\
(0.041)\end{array}$ & $\begin{array}{r}-0.394^{* * *} \\
(0.044)\end{array}$ \\
\hline$\Delta$ ShortDebt $_{t+1}$ & $\begin{array}{r}-0.292^{* * *} \\
(0.024)\end{array}$ & $\begin{array}{r}-0.066^{* *} \\
(0.033)\end{array}$ & $\begin{array}{r}-0.309^{* * *} \\
(0.036)\end{array}$ \\
\hline$\Delta \mathrm{RD}_{t+1}$ & $\begin{array}{r}0.288^{* * * *} \\
(0.048)\end{array}$ & $\begin{array}{r}-0.066 \\
(0.090)\end{array}$ & $\begin{array}{r}-0.169 \\
(0.130)\end{array}$ \\
\hline$\Delta$ Fix. Investment ${ }_{t+1}$ & $\begin{array}{r}0.161^{* * *} \\
(0.034)\end{array}$ & $\begin{array}{r}0.157^{* * *} \\
(0.045)\end{array}$ & $\begin{array}{r}0.075 \\
(0.048)\end{array}$ \\
\hline Firm-years & 18,440 & 2,263 & 3,198 \\
\hline Firms & 2,013 & 347 & 505 \\
\hline Test $\gamma_{\Delta R D}=\gamma_{\Delta \text { FixInv }}$, pvalue & 0.030 & 0.023 & 0.073 \\
\hline
\end{tabular}

Note: Estimates produced by OLS two-way fixed effects with cluster-robust standard errors, clustering by firm. ${ }^{*} p<0.10,{ }^{* *} p<0.05,{ }^{* * *} p<0.01$. 
Table 3: Robust two-step GMM estimates of $\Delta$ Cash

\begin{tabular}{lrrr}
\hline \hline & US & Germany & UK \\
& $(1)$ & $(2)$ & $(3)$ \\
\hline$\Delta$ Cash $_{t-1}$ & $-0.089^{* *}$ & $-0.195^{* * *}$ & $-0.207^{* * *}$ \\
& $(0.038)$ & $(0.049)$ & $(0.071)$ \\
Cash Flow $_{t}$ & $0.246^{* * *}$ & $0.269^{* * *}$ & $0.126^{* *}$ \\
& $(0.039)$ & $(0.055)$ & $(0.055)$ \\
$\Delta$ RD $_{t+1}$ & $0.671^{* * *}$ & $0.511^{* * *}$ & $0.856^{* *}$ \\
& $(0.184)$ & $(0.190)$ & $(0.404)$ \\
$\Delta$ Fix. Investment & $0.219^{* *}$ & 0.088 & 0.056 \\
& $(0.107)$ & $(0.072)$ & $(0.164)$ \\
$\Delta$ NWC $_{t}$ & $-0.247^{* * *}$ & $-0.121^{* * *}$ & $-0.323^{* * *}$ \\
& $(0.063)$ & $(0.044)$ & $(0.100)$ \\
$\Delta$ Short Term Debt $_{t}$ & -0.100 & 0.008 & $-0.326^{* * *}$ \\
& $(0.090)$ & $(0.065)$ & $(0.102)$ \\
\hline Firm-years & 17,813 & 2,306 & 3,202 \\
Firms & 2,006 & 352 & 505 \\
Instruments & 335 & 391 & 237 \\
$J$ & 337.669 & 312.251 & 213.486 \\
$J$ pvalue & 0.162 & 0.987 & 0.536 \\
AR $(2)$ pvalue & 0.251 & 0.238 & 0.705 \\
Test $\gamma_{\Delta R D}=\gamma_{\Delta \text { FixInv }}$, pvalue & 0.040 & 0.033 & 0.064 \\
\hline \hline
\end{tabular}

Notes: Two-step GMM-SYS estimates of $\Delta$ Cash are reported with robust standard errors in parentheses. Time fixed effects and a constant term are included in all specifications. ${ }^{*} p<0.10,{ }^{* *} p<0.05,{ }^{* * *}$ $p<0.01$. 
Table 4: Robust two-step GMM estimates of $\Delta$ Cash: Firm Size interactions

\begin{tabular}{|c|c|c|c|c|c|c|}
\hline & \multicolumn{2}{|r|}{$\overline{\mathrm{US}}$} & \multicolumn{2}{|c|}{ Germany } & \multicolumn{2}{|r|}{$\overline{\overline{U U K}}$} \\
\hline & (1) & $(2)$ & $(3)$ & (4) & $(5)$ & (6) \\
\hline \multirow[t]{2}{*}{$\Delta \operatorname{Cash}_{t-1}$} & $-0.071^{*}$ & $-0.098^{* *}$ & $-0.165^{* *}$ & $-0.133^{* *}$ & $-0.233^{* * *}$ & $-0.203^{* * *}$ \\
\hline & $(0.043)$ & $(0.042)$ & $(0.065)$ & $(0.059)$ & $(0.059)$ & $(0.076)$ \\
\hline \multirow[t]{2}{*}{ Small $\times \mathrm{CF}_{t}$} & $0.209^{* * *}$ & $0.191^{* * *}$ & $0.185^{*}$ & $0.202^{* * *}$ & $0.142^{* * *}$ & $0.185^{* *}$ \\
\hline & $(0.045)$ & $(0.047)$ & $(0.097)$ & $(0.065)$ & $(0.051)$ & $(0.073)$ \\
\hline \multirow[t]{2}{*}{ Medium $\times \mathrm{CF}_{t}$} & $0.171^{* * *}$ & $0.152^{* * *}$ & $0.126^{* *}$ & $0.183^{* * *}$ & $0.209^{* * *}$ & $0.249^{* * *}$ \\
\hline & $(0.039)$ & $(0.055)$ & $(0.060)$ & $(0.055)$ & $(0.072)$ & $(0.081)$ \\
\hline \multirow[t]{2}{*}{ Large $\times \mathrm{CF}_{t}$} & 0.076 & 0.027 & 0.080 & $0.136^{* *}$ & 0.090 & 0.129 \\
\hline & $(0.089)$ & $(0.051)$ & $(0.094)$ & $(0.060)$ & $(0.071)$ & $(0.120)$ \\
\hline \multirow[t]{2}{*}{$\Delta \mathrm{RD}_{t+1}$} & $0.464^{* *}$ & & $0.371^{*}$ & & $0.412^{*}$ & \\
\hline & $(0.185)$ & & $(0.200)$ & & $(0.219)$ & \\
\hline \multirow[t]{2}{*}{$\Delta$ Fix. Investment ${ }_{t+1}$} & $0.359 * * *$ & & -0.069 & & -0.017 & \\
\hline & $(0.130)$ & & $(0.103)$ & & $(0.102)$ & \\
\hline \multirow[t]{2}{*}{$\Delta \mathrm{NWC}_{t}$} & $-0.289^{* * *}$ & $-0.302^{* * *}$ & -0.037 & -0.073 & $-0.316^{* * *}$ & $-0.349 * * *$ \\
\hline & $(0.061)$ & $(0.060)$ & $(0.063)$ & $(0.050)$ & $(0.073)$ & $(0.095)$ \\
\hline \multirow[t]{2}{*}{$\Delta$ Short Term Debt $_{t}$} & $-0.167^{*}$ & $-0.227 * *$ & -0.001 & 0.024 & $-0.263^{* * *}$ & $-0.285^{* * *}$ \\
\hline & $(0.092)$ & $(0.091)$ & $(0.084)$ & $(0.068)$ & $(0.072)$ & $(0.110)$ \\
\hline \multirow{2}{*}{ Small $\times \Delta \mathrm{RD}_{t+1}$} & & $0.510^{* *}$ & & $0.636^{*}$ & & $0.889^{* *}$ \\
\hline & & $(0.210)$ & & $(0.349)$ & & $(0.432)$ \\
\hline \multirow[t]{2}{*}{ Medium $\times \Delta \mathrm{RD}_{t+1}$} & & 0.338 & & 0.080 & & 0.019 \\
\hline & & $(0.275)$ & & $(0.189)$ & & $(0.837)$ \\
\hline \multirow[t]{2}{*}{ Large $\times \Delta \mathrm{RD}_{t+1}$} & & 0.676 & & -0.028 & & -0.239 \\
\hline & & $(0.493)$ & & $(0.199)$ & & $(0.448)$ \\
\hline \multirow[t]{2}{*}{ Small $\times \Delta$ FInv $_{t+1}$} & & $0.346^{*}$ & & -0.003 & & 0.252 \\
\hline & & $(0.180)$ & & $(0.113)$ & & $(0.201)$ \\
\hline \multirow[t]{2}{*}{ Medium $\times \Delta$ FInv $_{t+1}$} & & -0.125 & & 0.178 & & 0.223 \\
\hline & & $(0.158)$ & & $(0.111)$ & & $(0.198)$ \\
\hline \multirow[t]{2}{*}{ Large $\times \Delta$ FInv $_{t+1}$} & & 0.221 & & 0.075 & & -0.442 \\
\hline & & $(0.136)$ & & $(0.208)$ & & $(0.445)$ \\
\hline Firm-years & 17,813 & 17,813 & 2,306 & 2,306 & 3,202 & 3,202 \\
\hline Firms & 2,006 & 2,006 & 352 & 352 & 505 & 505 \\
\hline Instruments & 361 & 520 & 194 & 409 & 497 & 209 \\
\hline$J$ & 363.345 & 524.516 & 171.063 & 293.772 & 446.868 & 161.801 \\
\hline$J$ pvalue & 0.155 & 0.150 & 0.484 & 1.000 & 0.810 & 0.857 \\
\hline $\operatorname{AR}(2)$ pvalue & 0.443 & 0.166 & 0.414 & 0.604 & 0.329 & 0.631 \\
\hline
\end{tabular}

Notes: Two-step GMM-SYS estimates of $\Delta$ Cash are reported with robust standard errors in parentheses. Time fixed effects and a constant term are included in all specifications. ${ }^{*} p<0.10,{ }^{* *} p<0.05$, ${ }^{* * *}$ $p<0.01$. 
Table 5: Robust two-step GMM estimates of $\Delta$ Cash: Dividend Payout Ratio interactions

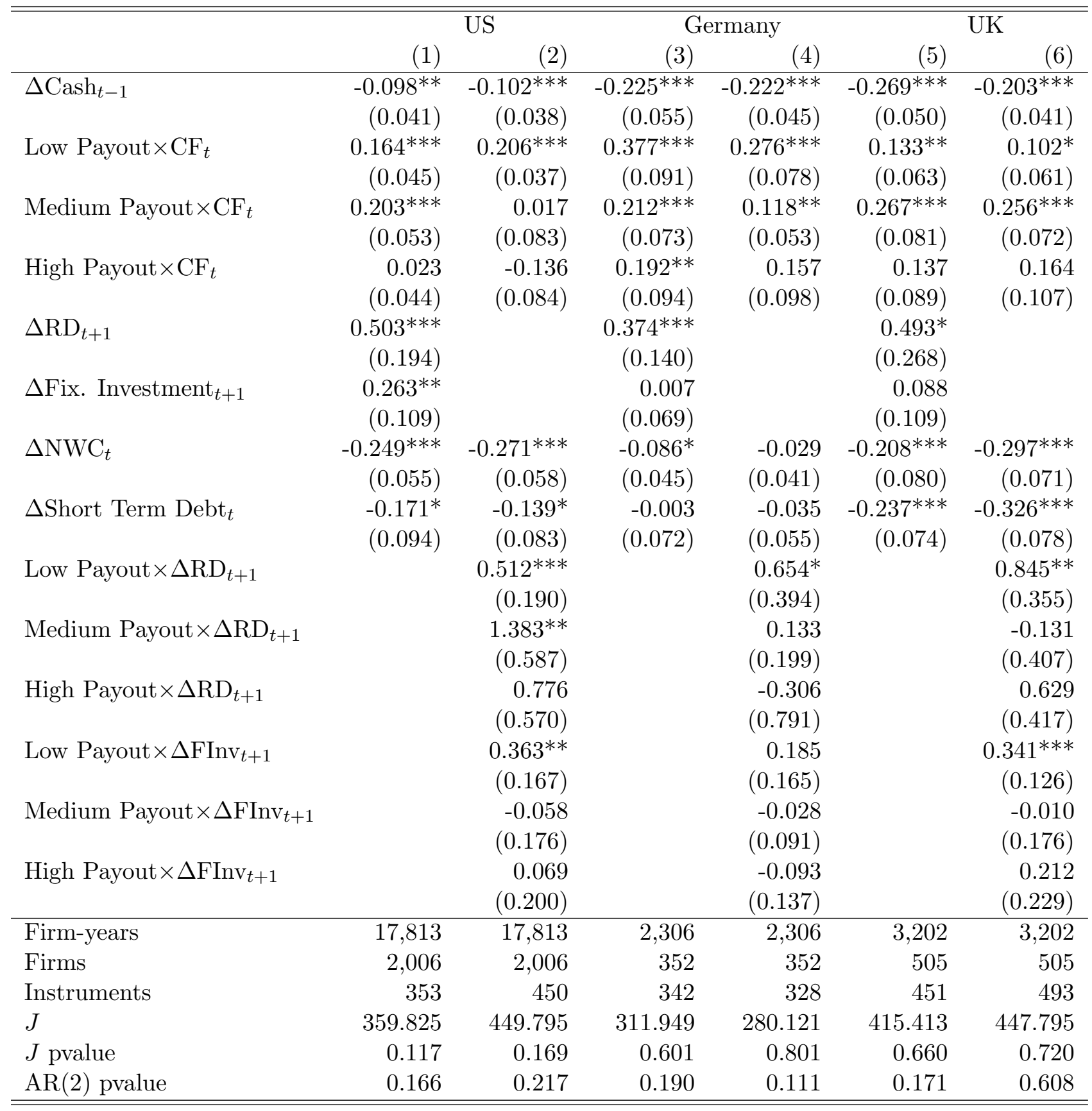

Notes: Two-step GMM-SYS estimates of $\Delta$ Cash are reported with robust standard errors in parentheses. Time fixed effects and a constant term are included in all specifications. ${ }^{*} p<0.10,{ }^{* *} p<0.05$, ${ }^{* * *}$ $p<0.01$. 
Table 6: Robust two-step GMM estimates of $\Delta$ Cash: Dividend Status interactions

\begin{tabular}{|c|c|c|c|c|c|c|}
\hline & \multicolumn{2}{|r|}{ US } & \multicolumn{2}{|c|}{ Germany } & \multicolumn{2}{|c|}{$\overline{\mathrm{UK}}$} \\
\hline & (1) & $(2)$ & $(3)$ & (4) & $(5)$ & (6) \\
\hline \multirow[t]{2}{*}{$\Delta \operatorname{Cash}_{t-1}$} & $-0.081^{*}$ & $-0.125^{* *}$ & $-0.193^{* * *}$ & $-0.211^{* * *}$ & $-0.256^{* * *}$ & $-0.190^{* *}$ \\
\hline & $(0.042)$ & $(0.062)$ & $(0.049)$ & $(0.056)$ & $(0.055)$ & $(0.092)$ \\
\hline \multirow[t]{2}{*}{ No $\operatorname{Div} \times \mathrm{CF}_{t}$} & $0.193^{* * *}$ & $0.191^{* * *}$ & $0.258^{* * *}$ & $0.253^{* *}$ & $0.214^{*}$ & $0.158^{*}$ \\
\hline & $(0.038)$ & $(0.048)$ & $(0.091)$ & $(0.112)$ & $(0.122)$ & $(0.094)$ \\
\hline \multirow[t]{2}{*}{$\operatorname{Div} \times \mathrm{CF}_{t}$} & $0.117^{* * *}$ & -0.089 & $0.215^{* * *}$ & $0.222^{* *}$ & $0.167^{* * *}$ & 0.086 \\
\hline & $(0.040)$ & $(0.090)$ & $(0.070)$ & $(0.094)$ & $(0.064)$ & $(0.077)$ \\
\hline \multirow[t]{2}{*}{$\Delta \mathrm{RD}_{t+1}$} & $0.533^{* * *}$ & & $0.475^{* *}$ & & $0.574^{*}$ & \\
\hline & $(0.177)$ & & $(0.192)$ & & $(0.333)$ & \\
\hline \multirow[t]{2}{*}{$\Delta \mathrm{Fix}$. Investment $_{t+1}$} & $0.217^{* *}$ & & 0.081 & & 0.039 & \\
\hline & $(0.109)$ & & $(0.081)$ & & $(0.091)$ & \\
\hline \multirow[t]{2}{*}{$\Delta \mathrm{NWC}_{t}$} & $-0.220^{* * *}$ & $-0.372^{* * *}$ & $-0.155^{* * *}$ & -0.050 & $-0.404^{* * *}$ & -0.248 \\
\hline & $(0.057)$ & $(0.113)$ & $(0.050)$ & $(0.046)$ & $(0.079)$ & $(0.178)$ \\
\hline \multirow[t]{2}{*}{$\Delta$ Short Term Debt $t_{t}$} & -0.134 & -0.073 & -0.073 & -0.030 & $-0.403^{* * *}$ & -0.210 \\
\hline & $(0.095)$ & $(0.160)$ & $(0.052)$ & $(0.075)$ & $(0.088)$ & $(0.197)$ \\
\hline \multirow[t]{2}{*}{ No Div $\times \Delta \mathrm{RD}_{t+1}$} & & $0.525^{* *}$ & & $1.766^{* * *}$ & & $1.115^{* * *}$ \\
\hline & & $(0.263)$ & & $(0.650)$ & & $(0.357)$ \\
\hline \multirow[t]{2}{*}{$\operatorname{Div} \times \Delta \mathrm{RD}_{t+1}$} & & 1.018 & & 0.001 & & -1.576 \\
\hline & & $(0.643)$ & & $(0.306)$ & & $(1.182)$ \\
\hline \multirow[t]{2}{*}{ No Div $\times \Delta$ FInv $_{t+1}$} & & 0.376 & & -0.501 & & 0.940 \\
\hline & & $(0.231)$ & & $(0.398)$ & & $(0.644)$ \\
\hline \multirow[t]{2}{*}{$\operatorname{Div} \times \Delta$ FInv $_{t+1}$} & & 0.140 & & 0.025 & & 0.260 \\
\hline & & $(0.205)$ & & $(0.085)$ & & $(0.182)$ \\
\hline Firm-years & 17,813 & 17,813 & 2,306 & 2,306 & 3,202 & 3,202 \\
\hline Firms & 2,006 & 2,006 & 352 & 352 & 505 & 505 \\
\hline Instruments & 349 & 174 & 380 & 194 & 334 & 362 \\
\hline$J$ & 353.093 & 128.674 & 288.255 & 150.975 & 294.859 & 37.902 \\
\hline$J$ pvalue & 0.145 & 0.884 & 0.997 & 0.850 & 0.749 & 0.796 \\
\hline $\operatorname{AR}(2)$ pvalue & 0.300 & 0.273 & 0.298 & 0.236 & 0.192 & 0.583 \\
\hline
\end{tabular}

Notes: Two-step GMM-SYS estimates of $\Delta$ Cash are reported with robust standard errors in parentheses. Time fixed effects and a constant term are included in all specifications. ${ }^{*} p<0.10,{ }^{* *} p<0.05$, *** $p<0.01$. 
Table 7: Robust two-step GMM estimates of $\Delta$ Cash: US subsamples

\begin{tabular}{|c|c|c|c|c|c|}
\hline & All & Small & Large & No Dividends & Dividends \\
\hline & (1) & $(2)$ & (3) & (4) & $(5)$ \\
\hline \multirow{2}{*}{$\Delta \operatorname{Cash}_{t-1}$} & $-0.080^{* *}$ & -0.088 & $-0.142^{*}$ & $-0.135^{* *}$ & -0.080 \\
\hline & $(0.036)$ & $(0.122)$ & $(0.080)$ & $(0.056)$ & $(0.066)$ \\
\hline \multirow[t]{2}{*}{ Cash Flow $_{t}$} & $0.226^{* * *}$ & $0.271^{*}$ & 0.171 & $0.327^{* * *}$ & $0.120^{*}$ \\
\hline & $(0.034)$ & $(0.146)$ & $(0.124)$ & $(0.058)$ & $(0.064)$ \\
\hline \multirow[t]{2}{*}{$\Delta \mathrm{RD}_{t+1}$} & $0.596^{* * *}$ & $1.702^{* * *}$ & $0.866^{* *}$ & $0.611^{* * *}$ & 0.341 \\
\hline & $(0.165)$ & $(0.532)$ & $(0.373)$ & $(0.190)$ & $(0.287)$ \\
\hline \multirow{2}{*}{$\Delta$ Fix. Investment $t_{t+1}$} & $0.224^{* *}$ & -0.014 & 0.356 & 0.013 & $0.344^{* * *}$ \\
\hline & $(0.098)$ & $(0.364)$ & $(0.343)$ & $(0.196)$ & $(0.099)$ \\
\hline \multirow[t]{2}{*}{$\Delta \mathrm{NWC}_{t}$} & $-0.238^{* * *}$ & $-0.805^{* * *}$ & -0.179 & $-0.407 * * *$ & $-0.158^{* *}$ \\
\hline & $(0.052)$ & $(0.309)$ & $(0.154)$ & $(0.109)$ & $(0.079)$ \\
\hline \multirow[t]{2}{*}{$\Delta$ Short Term Debt $_{t}$} & -0.139 & -0.755 & -0.234 & $-0.685^{* * *}$ & $-0.209^{*}$ \\
\hline & $(0.087)$ & $(0.619)$ & $(0.206)$ & $(0.226)$ & $(0.124)$ \\
\hline \multirow[t]{2}{*}{ New Equity Issuance ${ }_{t-1}$} & $0.125^{* *}$ & 0.133 & 0.372 & 0.147 & $0.338^{* *}$ \\
\hline & $(0.060)$ & $(0.245)$ & $(0.329)$ & $(0.109)$ & $(0.149)$ \\
\hline Firm-years & 17,318 & 3,618 & 4,607 & 6,849 & 10,152 \\
\hline Firms & 1,993 & 633 & 592 & 944 & 998 \\
\hline$J$ & 424.680 & 24.031 & 47.692 & 177.983 & 225.042 \\
\hline$J$ pvalue & 0.310 & 0.680 & 0.219 & 0.232 & 0.685 \\
\hline $\mathrm{AR}(2)$ pvalue & 0.643 & 0.902 & 0.095 & 0.975 & 0.218 \\
\hline Test $\gamma_{\Delta R D}=\gamma_{\Delta \text { FixInv }}$, pvalue & 0.057 & 0.020 & 0.280 & 0.032 & 0.992 \\
\hline
\end{tabular}

Notes: Two-step GMM-SYS estimates of $\Delta$ Cash are reported with robust standard errors in parentheses. Time fixed effects and a constant term are included in all specifications. ${ }^{*} p<0.10,{ }^{* *} p<0.05,{ }^{* * *}$ $p<0.01$. 